\title{
Covid adalah pageblug: Makna dan respon masyarakat terhadap pandemi di Desa Pancasila, Sukoreno Jember
}

\author{
Fitriatul Hasanah, Nur Hadi*, Ahmad Arif Widianto \\ Universitas Negeri Malang, Jl. Semarang No. 5 Malang, Jawa Timur, Indonesia \\ *Penulis korespondensi, Surel: nur.hadi.fis@um.ac.id
}

Paper received: 01-05-2021; revised: 15-05-2021; accepted: 30-05-2021

\begin{abstract}
The last decade of 2019, the world was in an uproar with the emergence of the corona virus disease (Covid-19) outbreak which first appeared in the city of Wuhan, China and spread throughout all countries including Indonesia. Covid-19 has had a significant impact in terms of socio-cultural and economic aspects. This study aims to describe the impact of Covid-19 which has contributed to the social transformation of the people of Pancasila Village, Sukoreno in maintaining the stability of government regulations against Covid-19. This research uses qualitative methods by collecting data through interviews and observations. Interviews were conducted with the village government, religious leaders, and the people of Pancasila Village, Sukoreno. The data analysis technique used an interactive model. The results showed that the 'pagebluk' paradigm is still strongly attached to rural communities in responding to the Covid-19 virus. Pagebluk is an assumption that is believed by the community in the form of "balak" or disease. This disease is believed to provide a deterrent effect to the community because they have neglected to carry out the orders and traditions in the Pancasila Village area, Sukoreno. The existence of Pagebluk causes social and cultural transformation in the local community. Various policies, regulations and agreements related to the handling of Covid-19 are relevant to changes in the socio-religious routine in society. The impact of Covid-19 is used as a strengthening of the relationships that are built in the community in dealing with Covid-19 by using the cultural basis and local wisdom of each religion and belief. The cultural-religious basis is the main aspect of carrying out social transformation by collaborating together across religions as a form of integrity in facing Covid-19. In addition, social reality confirms that the village level FKUB (Religious Forum for Religious People) can optimize the value of mutual cooperation in order to respond to the batara times that caused riots in a religious plural society. So that religious leaders have an important role in disciplining the community to carry out religious rituals in Pancasila Village, Sukoreno. social reality confirms that the village level FKUB (Religious Forum for Religious People) can optimize the value of mutual cooperation in order to respond to the batara times that caused riots in a religiously pluralistic society. So that religious leaders have an important role in disciplining the community to carry out religious rituals in Pancasila Village, Sukoreno.
\end{abstract}

Keywords: Covid-19; plural society; local culture; pagebluk

\begin{abstract}
Abstrak
Dekade terakhir tahun 2019, dunia di gemparkan dengan munculnya wabah corona virus disease (Covid-19) yang kali pertama muncul di Kota Wuhan, Cina dan menyebar ke seluruh negara termasuk Indonesia. Covid-19 menimbulkan dampak signifikan dalam aspek, sosial-budaya, dan ekonomi. Kajian ini bertujuan untuk mendeskripsikan dampak Covid-19 yang berkontribusi terhadap transformasi sosial masyarakat Desa Pancasila, Sukoreno dalam menjaga kestabilitasan peraturan pemerintahan melawan Covid-19. Penelitian ini menggunakan metode kualitatif dengan mengumpulkan data melalui wawancara dan observasi. Wawancara dilakukan dengan pemerintah desa, tokoh agama, serta masyarakat Desa Pancasila, Sukoreno. Teknik analisis data menggunakan model interaktif. Hasil penelitian menunjukkan bahwa paradigm 'pagebluk' masih melekat kuat terhadap masyarakat desa dalam menyikapi virus Covid-19. Pagebluk merupakan suatu asumsi yang diyakini oleh masyarakat yang berupa "balak" atau penyakit. Penyakit ini dipercaya akan memberikan suata efek jera kepada masyarakat karena telah lalai dalam menjalankan perintah dan tradisi di wilayah Desa Pancasila, Sukoreno. Adanya Pagebluk menyebabkan transformasi sosial dan budaya pada masyarakat setempat. Berbagai kebijakan, regulasi dan kesepakatan terkait penanganan Covid-19 berelevansi terhadap perubahan rutinitas sosial keagamaan di masyarakat.
\end{abstract}


Dampak Covid-19 dijadikan sebagai penguat relasi yang terbangun di masyarakat dalam merentas Covid-19 dengan menggunakan basis budaya dan kearifan lokal pada masing-masing agama dan aliran kepercayaan. Basis budaya-agama menjadi aspek utama melakukan transformasi sosial dengan melakukan kolaborasi bersama lintas agama sebagai wujud integritas menghadapi Covid-19. Selain itu, realitas sosial menegaskan bahwa FKUB (Forum Keagamaan Umat Beragama) tingat desa dapat mengoptimalkan nilai kegotongroyonga guna menyikapi batara kala yang menyebabkan kerusuhan di tengah masyarakat plural beragama. Sehingga tokoh agama memiliki peran penting dalam mendisiplinkan masyarakat untu melaksanakan ritual keagamaan di Desa Pancasila, Sukoreno.

Kata kunci: Covid-19; masyarakat plural; kearifan lokal; pagebluk

\section{Pendahuluan}

Dekade terakhir tahun 2019 seluruh dunia digemparkan dengan Corona Virus disease berasal dari Kota Wuhan Cina yang menyebar di beberapa negara, termasuk Indonesia. Covid19 di Indonesia meresahkan seluruh lapisan masyarakat, dan melumpuhkan sektor sosial, ekonomi, politik, bahkan pendidikan. Permasalahan ini menjadi suatu diskursus pelik dalam dunia medis, karena peningkatan orang yang terinfeksi Covid-19 sangat pesat. Pada 18 Oktober 2020 masyarakat yang teridentifikasi Covid-19 mencapai $64.032(17,689 \%)$ jumlah kasus aktif, 4.105 penambahan kasus positif corona, $285.324(78,85 \%)$ jiwa yang dinyatakan sembuh, dan $12.511(3,46)$ jumlah kasus meninggal (WHO Indonesia / World Health Organization, 2020). Adapun dalam hal ini, upaya perentasan Covid-19 juga dilakukan melalui strategi kebijakan yang dikeluarkan oleh pemerintahan. System Lock-Down merupakan salah satu kebijakan yang diterapkan. Pada dasarnya strategi tersebut justru menyebabkan masyarakat terjerumus pada kondisi dan situasi ketakutan (panik). Keresahan masyarakat tersebut berimplikasi pada kiat-kiat yang harus dibangun oleh individu untuk kesejahteraan jiwa saat terdapat kondisi mendesak (Covid-19) (Buana, 2017). Selain itu pemerintah juga melakukan social distancing dan physical distancing, semua peraturan tersebut terangkum dalam protokol kesehatan yang ditetapkan. Akan tetapi berbagai penanganan juga dilakukan oleh masing-masing daerah untuk merentaskan rantai Covid-19 baik di desa maupun di Kota. Peraturan daerah pun turut andil dalam penanganan Covid-19 yang cenderung menggunakan kearifan lokal setempat (Funay, 2020).

Dampak Covid-19 juga dirasakan oleh masyarakat plural Kabupaten Jember sebagai wilayah melting pot dengan berbagai suku, bangsa, agama dan bahasa. Keragaman agama di Jember sangatlah tinggi, sebagaimana menurut data BPS Kab. Jember (2020) tercatat jember memiliki 2.294.519 jiwa beragama Islam, 28.926 jiwa beragama protestan, 19.288 jiwa beragama Katolik, 1.609 jiwa beragama Hindu, 3.401 jiwa beragama Budha, 343 jiwa kepercayaan lainnya. Basis keragaman agama dan laku ritual yang ada di wilayah Kabupaten Jember menjadi orientasi utama dalam memutus rantai Covid-19. Peraturan masing-masing daerah diterapkan untuk dapat mengantisispasi penulara Covid-19 secara meluas. Adapun update data Covid-19 Jember data per 19 Oktober 2020 di Kabupaten Jember, mengetahui masyarakat yang teridentifikasi positif corona mencapai 1043 yang masih dirawat $(9,59 \%)$, pasien sembuh 888 (85,14\%), pasien dalam pantauan 161 (4,16\%), kasus suspek 36, dan total pasien meninggal dunia yakni 55 (5,27\%) (Maharani, 2020). Tingginya masyarakat yang terindetifikasi Covid-19 di wilayah Jember ini menekankan kebijakan pemerintah pusat untuk melakukan koordinasi dengan pemerintah daerah. Sehingga dalam hal ini perana pemerintah daerah merupakan pusat utama dalam melakukan pendisplinan dan penertiban masyarakat. 
Menurut Hengki \& Masmini (2020) menyatakan bahwa komunitas masyarakat desa memiliki strategi berbasis budaya dalam menyikapi pandemic Covid-19. Adapun di Kabupaten Jember terdapat salah satu wilayah yang memiliki basis ritual dalam menanggapi Covid-19 yakni Desa pancasila Sukoreno. Desa Sukoreno merupakan salah satu wilayah di Kecamtan Umbulsari yang memiliki keragaman agama dan budaya yakni agama Islam, agama Hindu Krisna dan Hindu Darma, agama Kristen, dan agama Katolik, serta aliran Kepercayaan Sapta Darma dan Ilmu Sejati. Keragaman agama ini berorientasi pada munculnya budaya dan tradisi di Desa Pancasila, Sukoreno dalam merentas pandemic Covid-19.

Sebagaimana menurut Ulya (2020), pemerintah daerah memiliki alternative strategi yang diterapkan dalam penanangan dampak Covid-19 melalui kerjasama antar masyarakat guna membangun perekonomian pada kawasan Agropolitan. Sunuantari \& Zarkasi (2020) menegaskan bahwa tata kelola pada masing-masing wilayah memiliki perbedaan, khususnya pada masyarakat pedesaan yang cenderung mengedepankan basis komunitas dalam menyikapai Covid-19. Penangaan Covid-19 di desa pancasila Sukoreno juga memilii perbedaan dengan wilayah lain. hal ini dilatarbeakangi karena keragaman agama dan ras multikulture yang dimiliki oleh masyarakat. dengan demikian memiliki strategi tersendiri dalam merentas Covid-19 khususnya berbasis ritual keagamaan dan kearifan lokal. Selain itu asumsi kuat yang dimiliki oleh masyarakat Desa pancasila, Sukoreno ini merujuk bahwa covid-19 is pagebluk, analisis makna yang terkandung dalam penyebaran Covid-19 ini adalah bukan masyarakat tidak mempercayai terkat adanya pandemic Covid-19 ini, namun masyarakat lebih mengenal virus tersebut dengan makna pagbeluk. Pagebluk merupakan representasi dari makna simbolik yang dimiliki oleh masyarakat Desa Pancasila, Sukoreno dalam menyikapi pandemic Covid-19. Pagebluk ini merujuk pada pemaknaan wabah penyakit yang disebabkan oleh murkanya Batara Kala kepada masyarakat. Menurut Arifin (2020) menyatakan bahwa pagbeluk merupakan suatu makna dari penyebaran Covid-19 menurut perspektif masyarakat desa. Adapun dalam prentasan Covid-19 bagi masyarakat desa pancasila, dapat dilakukan dengan diam diri di rumah masing-masing dan melakukan sujud, sebgaai upaya untuk mengendalikan diri dan pendekatakan diri kepada ajaran Tuhan YME.

Pandemi Covid-19 menyebabkan lumpuhnya berbagai ritual keagamaan di desa pancasila, Sukoreno. Sehingga dalam hal ini menyebabkan transformasi sosial masyarakat untuk merentas pandemic Covid-19 dengan peranan tokoh agama berbasis kearifan lokal. Keyakinan yang masih dipegang teguh mengantarkan masyarakat untuk tetap dalam kondisi tenang dan "sujud" (Ismail, 2018). Ritual keagamaan menjadi aspek utama guna menyelaraskan warga untuk tetap waspada menghadapi pandemic Covid-19 berbasis teologis dan metafisika. Hal ini dipengaruhi karena nilai dan Norma yang dimiliki oleh masyarakat Desa Pancasila Sukoreno memberikan perspektif bahwa Covid merupakan pagebluk yang dapat menimbulkan banyak korban jiwa. Lebih lanjut Covid-19 bukanlah penyakit mematikan pertama di masyarakat Desa pancasila, Sukorneo. Sebelumnya pagebluk sudah marak terjadi di lingkungan masyarakat sebagai suatu pengingat ataupun makna yang berelevansi terhadap lemahnya kegiatan laku ritual antara Tuhan dengan manusia. Dengan demikian dalam pengendalian penyebaran Covid-19 di Desa Pancasila Sukoreno menggunakan basis ritual keagamaan yang dipimpin oleh tokoh agama di wilayah setempat. Basis ritual yang dijalankan oleh warga Sukoreno dilaksanakan secara bergotong royong dengan mengedepankan asas toleransi antar umat beragama. Yasa (2020) mengemukakan bahwa penanganan Covid-19 pada masyarakat adat Desa Bali berlandasakan pada Tri Hita Karana atau basis pendekatan religiusitas. 
Susanto et al., (2020) menyatakan dalam merentas pandemic Civid-19 dan menghadapi normal baru di masyarakat menggunakan basis tradisi keagaaan sebaagi wujud pelestarian budaya di Jawa. Upaya perentasan Covid-19 juga menjadi tanggung jawab Pecalang dan Banjar adat di Tanggahan Tengah (Ningrum, 2021). Lebh lanjut penelitian yang dilakukan oleh Dozan \& Wadi (2021) menegaskan bahwa agama dan media baru memiliki relevansi terhadap aspek kesadaran eologi manisia di tengah pandemic. Dari penelitian terdahulu dapat disimpulkan bahwa urgensi peneitian yang dilakukan adalah dengan mengarah pada anlisis makna masyarakat desa Pancasila, Sukoreno terkait paradigma pagbeluk, serta upaya penyikapan Covid-19 melalui regulasi peranan lintas agama. Lebih lanjut terkait analisis makna dan simbolik dalam merepresentasikan kajian laku ritual pada masing-masing umat beragama. Adapun tujuan dalam penelitian yang dilakukan adalah mendeskripsikan terhadap permasalahan makna corona is hoax dalam analisis pagebluk di masyarakat serta mengetahui laku ritual dalam perentasan covid-19 antar umat beragama. Manfaat yang dapat diambil adalah masyarakat lebih mengenal penyikapan perentasan covid-19 dan normal baru di Desa pancasila Sukoreno melalui laku ritual dan kerjasama lintas agama. selain itu manfaat lain bagi pemerintah yakni dapat dijadikan sebagai bahan kajian untuk memperkuat system peraturan terkait penanganan Covid-19 dengan melakukan kerjasama dengan pemerintah daerah melalui basis laku ritual dan keagamaan.

\section{Metode}

Penelitian ini dilakukan di Desa Pancasila, Sukoreno, Kecamatan Umbulsari, Kabupaten Jember. Adapun fokus penelitian yang dilakukan bukan hanya berorientasi secara geografis, namun juga secara sosiologis dengan mendeskripsikan kompleksitas hubungan yang terjalin antar masyarakat plural melalui kerja Sama dalam penangan Pandemi Covid-19 melalui kearifan lokal yang dimiliki. Selain itu fokus penelitian juga terkait makna simbolik dari eksistensi pagebluk yang terkenal di masyarakat Desa pancasila Sukoreno, sehingga kepercayaan masyarakat terhadap Covid-19 cenderung tidak ada. Peradigma makna dan nilai terhadap Pagebluk is Covid ini merupakan orientasi utama dalam pengolahan data yang berelevansi terhadap laku ritual yang dilaksanakan masuyarakat. Substansi waktu penelitian dilaksanakan pada bulan Juli 2020 hingga bulau April 2021 di Desa Sukoreno. Subjek penelitian merupakan masyarakat desa Sukoreno yang memiliki kemajemukan dalam unsur sosial dan budaya, khususnya pada multi agama dan aliran kepercayaan di masyarakat. Penelitian ini menggunakan metode kualitatif untuk dapat menggali data dan memahami fenomena sosial secara mendalam di masyarakat dengan menggunakan triangulasi data dari informasi yang didapatkan (Moleong, 2004). Selain itu metode ini juga menekankan pada analisa deskrisi data secara mendalam yang merupakan salah satu unsur penelitian fenomenologi dengan melihat kajan fenomena dari sudut pandang aktor sosial dan pemahaman mengenai proses sosial daripada aspek statistik sosial (Blalkie, 2000). Penelitian kualitatif dalam mempertajam logika berpikir dalam pengumpulan data dan analisis data menggunaka abstraksi induksi. Abstraksi induksi merupakan suatu aliran pemikiran dari khusus ke umum yakni kategorisasi, konseptualisasi, dan deskripsi berdasarkan hasil lapangan (Faisal, 2015). Prosedur dan karakteristik dari penelitian kualitatif relevan dengan desain penelitian yang dilakukan yaitu memetakan terhadap model dan struktur kohesi sosial dalam masyarakat multi-agama. Sehingga dalam hal ini membutuhkan data secara mendalam terkait proses sosial masyarakat di tengah Covid-19.

Pengumpulan data dilakukan dengan menggunakan observasi yang bertujuan untuk: Pertama, dapat memahami tatanan sosial adat masyarakat plural secara alamiah dan 
mendalam. Kedua, menangkap suatu peristiwa yang dapat mempengaruhi proses sosial dan fokus penelitian. Ketiga, mengidentifikasikan terhadap keteraturan sosial yang terdapat pada realitas sosial pada masyarakat. Keempat, melakukan pemahaman terhadap realitas sosial dari perspektif subjek penelitian (Black \& Campion, 2009). Peneliti dalam penelitian kualitatif berperan sebagai instrument kunci (Setiawan, 2018). Selain itu lebih lanjut Rukajat (2018) menyatakan bahwa Penelitian dan pengamatan dilakukan secara partisipatif di masyarakat Desa Pancasila, Sukoreno dan fokus terhadap pengamatan proses sosial, pranata dan struktur sosial, pola interaksi dan relasi antar kelompok agama, selain itu juga terhadap laku ritual dan tradisi yang berlangsung, simbol dan realitas sosial yang mempengaruhi dan mendukung dari fokus penelitian tersebut. Selain observasi juga dilakukan wawancara secara mendalam dengan informan untuk mendapatkan gambaran yang lengkap tentang data-data yang dibutuhkan. Informan dipilih melalui teknik purposive sampling yakni pemilihan yang dilakukan berdasarkan kemampuan dan ketepatan informan mengenai data yang dibutuhkan (Wijaya, 2018). Informan tersebut terdiri dari perangkat desa tokoh agama, karang taruna, pegiat sosial keagamaan dan masyarakat sekitar. Setelah melakukan pengumpulan data, maka akan dianalisis menggunakan model analitik interaktif dengan pengumpulan data dan prosesnya lebih bersiklus dan tidak linier (Faisal, 2015). Analisis data dilakukan sejalan dengan proses pengumpulan data untuk verifikasi data. Sehingga diperoleh data yang valid, reliable, dan objektif, data yang terkumpul direduksi menjadi pemilahan informasi yang relevan dan disusun dalam asumsi (persepktif) logika induktif.

\section{Hasil dan Pembahasan}

\subsection{Pagebluk: Perspektif Masyarakat Terhadap Makna Covid-19 Berbasis Kearifan Lokal}

Covid-19 merupakan salah satu penyakit yang berasal dari Kota Whan Cina pada dekade tahun 2019. Penyakit ini memiliki dampak signifikan bagi masyarakat yakni dalam bidang ekonomi, sosial, agama, maupun pendidikan. Sebagaimana menurut Ilpaj \& Nurwati (2020) Covid-19 menyebabkan banyak kerugian bagi masyarakat terutama korban jiwa dan Livana et al., (2020) juga menyatakan bahwa pandemic juga berdampak pada aspek sosial ekonomi pada masyarakat. Meningkatnya masyarakat yang terindikasi Covid memunculkan kiat-kiat dalam melakukan transformasi ekonomi, sosial dan budaya di masyarakat guna merentas Covid-19 (Gani et al., 2020). Desa Pancasila Sukoreno, adalah salah satu wilayah yang berada di Kecamatan Umbulsari, kabupaten Jember ini memiliki kebijakan tersendiri dalam menangani pandemic Covid-19. Hindaryatiningsih (2016) model pewarisan nilai budaya bagi masyarakat desa disosialisasi menjadi tiga bentuk tradisi yakni nilai budaya, dalam tradisis dan kepercayaan, ritual eagamaan dan tradisi sikulus hidup manusia, sebagai upaya dalam menyikapi suatu diskursusu sosial di lingkungannya. laku ritual budaya maupun tradisi yang dilakukan dalam perentasan Covid-19 merupakan representasi bagi masyarakat sebagai basis kepercayaan terhadap aspek teologis dan metafisika. Ritual menjadi sarana mediasi bagi masyarakat untuk melakukan komunikasi terhadap Tuhan dan kekuatan ghaib sebagai bentuk permohonan perlindungan dan pertolongan terhadap penyebaran virus Covid-19. Dalam penelitian Nasrulloh (2020) menegaskan bahwa upacara ritual Bareqe dilaksanakan masyarakat Pare-Pare sebagai upaya untuk menghadapi pandemic Covid-19.

Basis tradisi ini berelevansi pada keyakinan masyarakat yang tdak mempercayai adanya Covid-19. masyarakat bukan sepenuhnya tidak meyakini keberadaan Covid-19 di Indonesia, 
terutama pada wilayah DesaPancasila, Sukoreno. Namun masyarakat lebih mengenak bahwa Covid-19 merupakan pagebluk. Adapun makna dari pagebluk ditinjau dari Kamus Besar Bahasa Indonesia adalah "wabah" atau "penyakit" (KBBI Online, 2020). Sebagaiamana menurut Rumilah et al., (2020) masyarakat Jawa telah mengenal penyakit yang hampir sama dengan Covid-19 sehingga menyebabkan kematian pada masyarakat. lebih lanjut masyarakat percaya bahwa penyakit tersebut merupakan pagebluk yang lebih mengarah pada makna kosmis mistis. Analisis pagebeluk bagi masyarakat Desa Pancasila Sukoreno menyatakan bahwa, pagebluk merupakn suatu wujud penyakit yang didatangkan oleh Batara Kala kepada umat manusia karena kelalaiannya dalam melakukan peribadatan. Asumsi ini dipertegas oleh Yusuf \& Basyid (2020) yang mengemukaka bahwa Covid-19 adalah orientasi dari pagbeluk yakni keyakinan masyarakat terhadap penyakit diturunkan oleh kekuatan ghaib kepada manusia sehingga memerlukan suatu ritual untuk tolak bala. Masyarakat Desa pancasila Sukoreno memaknai pagebluk dengan hukuman yang diberikan kepada masyarakat, karena kelalaiannya dalam melakukan ibadah dan laku ritual keagamaan. Pagebluk Covid-19 bukanlah kali pertama penyakit yang menyerang ke Desa Pancasila Sukoreno. Sehingga dalam hal ini masyarakat sudah mengetaui terhadap strategi yang harus dilakukan untuk merentas Covid-19.

Pagbeluk Covid-19 bagi masyarakat Desa Pancasila Sukoreno memiliki beberapa makna, diantaranya Pertama, masyarakat mempercayai bahwa Covid-19 merupakan pagebluk yang diturunkan oleh Tuhan dengan mengutus batara kala untuk menciptakan kekacauan dan kematian di masyarakat. Kedua, Pagebluk merupakan representasi dari tingkah laku masyarakat yang telah mengalami kekacauan dengan ditandai dengan rusaknya moral sebagaimana marakanya kasus bapa akawin anak atau anak akawin biyung (bapak menikahi dan menghamili anak atau anak menikahi dan menghamili ibu) oleh karena itu Tuhan mendatangnkan peyakit sebagai efek jera terhadap masyarakat. Ketiga, Pagebluk dipercaya sebagai penyakit yang akan menyerang daya tahan tubuh, sehingga masyarakat perlu menyiapkan diri dengan melakukan pendekatan rohani kepada Tuhan dan pendekatan Jasmani teerhadap laku ritual budaya di masyarakat setempat.

Ditinjau dari analisis makna terhadap Covid is Pagebluk menurut perspektif masyarakat Desa Pancasila, Sukoreno, diketahui bahwa setiap laku ritual dan feomena sosial merepresentasikan dari nilai dan norma di masyarakat. wabah penyakit Covid-19 ini memiliki simbol-simbol tersendiri bagi masyarakat untuk menjewantahkan pagbeluk dengan basis ritual keagamaan yang dijalankannya. Sebagaimana menurut Setiawan \& Kurniawan (2017) dalam teori intersionisme simbolik Blumer menyatakan bahwa segala perilaku dan tindakan yang dilakukan oleh masyarakat memiliki makna dan simbol tersendiri untuk memberikan isyarata maupun komunikasi dengan masyarakat lainnya. Setio (2020) pagebluk Covid-19 memiliki multi tafsir dalam merepresentasikan arti ataupun makna dari keberadaannya. Wabah pagebluk covid-19 djadikana sebagai pola interkasi dankomunikasi antara Tuhan dan kekuatan adikodrati kepada manusia. Penyakit yang marak di tengah kehidupan masyarakat merupakan suau simbol, bahwa pada hakikatnya manusia harus tetap berada dalam keadaan taat dan iman, dengan melakukan pekerjaan di luar rumah secara wajar, dan kembali lagi untuk mengatarkan dirinya menghadap pencipta (Tuhan). Adanya virus Covid-19, pemerintah melakukan kebijakan baru diantaranya PSBB, Social Distancing, Phisycal Distancing dan lainlain. adapun orientasi dari kebijakan tersebut yakni mengembalikan individu untuk kembali ke rumah dan tidak melakukan aktivitas di luar apabila tidak penting. Dengan kebijakan tersebut pada dasarnya merupakan relevansi adanya makna dari pandemic Covid-19. Dalam hal ini, dengan adanya kebijakan tersebut masyarakat lebih mendekatkan diri kepada Tuhan 
dan tidak melakukan kerusakan di lingkungan sekitar. pada dasarnya manusia merupakan indivdu yang menyebabkan kerukana ekologis di sekitarnya. Pengetahuan yang dimilikinyajustru membuat lingkungan tidak stabil dan mengalami global warming sehingga dapat mengubah suhu di lingkungan sekitar sehingga berpotensi meneybabkan kerukan dan maraknya penyakit yang akan meneyrang masyarakat. dengan demikian, adanya pagebluk tersebut memberikan makna simbolik bagi masyarakat untuk tetap berada dalam keadaan suju untuk merentas Covid-19 di pedesaan khususnya pada masyarakat Desa Pancasila, Sukoreno.

\subsection{Ritual Agama dan Budaya dalam Merentas Pandemi Covid-19}

Masyarakat Sukoreno juga masih percaya bahwa Covid19 merupakan "pagebluk" yang merupakan sebuah penyakit mematikan tanpa sakit, sehingga antisipasi juga datang dari masyarakat setempat dengan melakukan laku ritual di masing-masing agama yang dianutnya. Ritual keagamaan sebagai wujud perspektif haluan metafisika yang diberikan oleh masyarakat untuk menghadapi Covid-19. Menurut analisis Somawati et al., (2020) dalam buku "Bali vs Covid" menyatakan bahwa masyarakat adat cenderung menggunakan basis budaya untuk menangkal "bala" atau penyakit yang ditimbulkan oleh Covid-19. Penanganan Covid-19 berbasis ritual lokal dapat diidentifikasikan sebagai sarana untuk melakukan "uri-uri budaya". Kearifan lokal merupakan sumber modal sosial guna memberdayakan masyarakat (Suaib, 2017a). Laku ritual ini tentunya sudah mendapatkan perizinan dari pihak desa setempat, sehingga penjagaan dan keamanan pada saat masyarakat melakukan ritual keagamaan juga diperketat. Ritual keagamaan ini juga diikuti oleh perangkat desa, sehingga semua agama yang melaksanakan laku ritual masing-masing tetap berada di dalam pengawasan dan pemantauan dari pihak keamanan, kesehatan, dan juga pemerintahan desa setempat. Ritual tolak bala Covid-19 ini dilakukan oleh seluruh umat beragama di Desa Sukoreno dengan cara yang berbeda-beda namun tujuannya sama. Antara masyarakat dan umat saling mengingatkan untuk membuat penangkal secara individu ataupun kelompok yang ditaruh di depan rumah. Seperti "wong-wongan" agama Hindu, dan sajen oleh agama penganut agama lainnya. Hal demikianlah wujud partisipasi yang timbul di desa Sukoreno sebagai upaya pencegahan penangan Covid-19. Adapun persiapan yang dilakukan oleh pihak pemerintah Sukoreno pada saat masyarakatnya akan melakukan laku ritual diantaranya adalah, menyediakan handsanitizer, pengawasan dan pemantauan, pemeriksaan kesehatan, dan juga turut serta mengikuti agenda yang ada. Ritual ini merupakan kepercayaan yang dianut oleh masyarakat setempat secara turun temurun dan menjadi suatu tradisi untuk menghilangkan balak bagi masyarakat setempat. Adapun ritual keagamaan yang dilaksanakan di Sukoreno diantaranya adalah:

\subsubsection{Ritual Ambengan}

Masyarakat Muslim di desa Sukoreno mengadakan selametan keagamaan dengan cara ambengan, ambengan ini bukan hanya di khususnya kepada masyarakat Muslim saja, namun juga terhadap masyarakat lintas agama. Untuk masyarakat lintas agama yang ingin bergabung maka membawa rege (tempat untuk membawa ambeng yang terbuat dari pelepah pisang dan bambu). Ambengan tersebut dibawa di masjid terdekat untuk diadakan berdoa bersama dan istighosah. Sebagaimana menurut Ahwan \& Marzuki (2020) menyatakan bahwa ambengan termasuk dalam tradisi bari'an sebagai wujud interaksionisme simbolik bagi masyarakat dan aspek teologis maupun metafisi yang masih dipercaya oleh masyarakat di Jawa Ambeng 
tersebut berisi nasi punar, telur, ikan ayam, dan juga "pendeman" atau ubi-ubian. Adapun makna dari ambeng tersebut diantaranya adalah: (1) Nasi punar, melambangkan Dewi Sri (pembawa keberkahan) yang merupakan hasil panen dari masyarakat setempat mayoritas mata pencahariannya sebagai petani. Dengan demikian diharapkan agar masyarakat setempat selalu mendapatkan keberkahan di tengah Covid19 ini. (2) Telur, dapat melambangkan sebagai suatu beban, sehingga dalam hal ini apabila diberikan cobaan berupa musibah Covid-19 selayaknya sebagai manusia beragama tetap bersabar, bertawakal, dan berikhtiar, sehingga beban yang ada sama-sama dipikul oleh semua masyarakat yang ada, yakni dengan cara saling mengingatkan, menjaga kesehatan, dan menjaga jarak. (3) Ikan ayam, merupakan wujud dari "ingon-ingon" atau peliharaan masyarakat desa, dan dapat disimbolkan mendapatkan keberkahan dan kebermanfaatan. Sehingga apabila diimplementasikan dengan Covid-19, diharapkan masyarakat dapat mengambil hikmah dan manfaat adanya covid dengan peraturan dan kebijakan yang diberlakukan oleh pemerintah setempat (4) Pendeman merupakan simbol dari kehidupan manusia yang berasal dari tanah dan akan kembali di tanah (dikebumikan) sehingga dalam hal ini masyarakat harus tetap semangat dalam menghadapi covid dan juga berdoa untuk mendekatkan diri kepada Tuhan.

\subsubsection{Upacara nunas ica'}

Upacara nunas ica' merupakan upacara ayang dilaksanakan oleh agama Hindu di masyarakat Sukoreno khususnya Hindu Dharma. Pada masyarakat Hindu Dharma ini melakukan ritual keagamaan dengan membawa canang. Dalam hal ini masyarakat desa Sukoreno juga mengikuti terhadap instruksi tokoh agama Hindu yakni wakil ketua parisada hindu Indonesia (PHDI) pelaksanaan upacara nunas ica dilaksanakan pada tanggal 30 Maret 2020, sebagai upaya dalam pencegahan Covid19 dengan menggunakan adat dan ritual keagamaan Hindu upacara Nunas Ica Kerahayuan ini ditujukan kepada Ida Bhatara Sasuhunan sebagai bentuk keharmonisan, karma, dan budaya. Adapun pelaksanaan ritual keagamaan adalah sebagai berikut: Pertama, Upacara serentak dilaksanakan pada hari selasa (anggara Umanis, wuku krulut) pada tanggal 31 Maret 2020, dengan menyampaikan pejati, dan Nyejer sampai dengan covid-19 berakhir, dan terus akan melaksanakan pemerataan lebih lanjut. Kedua, Nunas Ica dilaksanakan bersama pamangku di masing-masing pura dengan cara nyejer daksinapati wabah covid-19 berakhir. Ketiga, Memohon doa kepada Ida Bhatara Sasuhunan yang disesuaikan dengan dreshta desa adat setempat agar wabah covid-19 segera berakhir. Keempat, Untuk pelaksanaan upacara di pura Desa Adat dapat dilaksanakan pada tanggal 2 April sampai 7 April 2020, untuk dapat menghaturkan banten pejati dengan dilengkapi dengan bungkak gadang atau bungkak gading yang dilaksanakan setiap hari.

Kelima, Pelaksanaan upacara telah jatuh pada tanggal 2 April 2020 yakni: dilaksanakan di marajen atau sanggah keluarga dengan menghanturkan banten pejati dilengkapi dengan bungkak gadang atau bungkak gading dan dilaksanakan di lebuh pekarangan: menghaturkan nasi wong-wongan, ulam bawang jahe, dan garam, beralas muncuk daun pisang (don telunjungan) dengan ketentuan sebagai berikut: 1) Kepala warna putih (makna warna putih dengan dewa Iswara yang bersenta Bajra, berada di sebelah timur, dan dengan tanda jantung mempunyai makna matahari, pelebur, dan sumber kebangkitan). 2) Tangan kanan warna merah (makna warna merah yang berada di selatan dengan dewa Brahma dengan pusaka Gada dan tanda api memiliki makna budaya laut, pencipta dan kekuatan). 3) Tangan kiri warna kuning (makna warna kuning di sebelah barat dengan dewa Mahadewa dengan senjata Nagasapah dan tanda lingkungan kabut memiliki makna budaya matahari terbenam, penjaga 
keseimbangan dan kekuasaan). 4) Badan macam warna (warna brumbun yang merupakan campuran warna putih, kuning, hitam, dan merah yang berada di tengah dengan Dewa Ciwa bersenjata Padma dan tanda lingkungan topan memiliki makna budaya pusat, pemusnah dan dasar dari semua unsur, kesucian). 5) Kaki warna hitam (makna warna hitam yang berada di sebelah utara dengan dewa Wisnu menurut budaya Hindu berarti gunung, dengan fungsi sebagai pemeliharaan).

\subsection{Strategi Tokoh Agama dan Pemuda Desa Dalam Menghadapi Era New Normal Covid-19 Pada Masyarakat Plural Desa Pancasila}

Kerjasama lintas agama dalam memutus rantai Covid-19 terangkum atas heteorgenitas agama di wilayah Sukoreno. Agama yang terdapat di Desa Pancasila Sukoreno diantaranya adalah agama Islam sebagai agama mayoritas (NU dan Muhammadiyah), agama Hindu (Hindu Dharma dan Hindu Krisna), agama Kristen (Protestan dan Katolik), dan penghayat kepercayaan (Sapta Dharma dan Ilmu Sejati). Perbedaan agama ini dileburkan oleh kerja Sama lintas agama dalam menjunjung budaya dan tradisi yang masih berkembang di masyarakat sekitar. Masyarakat dan tokoh agama dalam menyikapi Covid yakni melakukan ritual peribadatan dengan menggunakan mantram, dan juga wong-wongan yang di berfungsi untuk melakukan "tolak balak" dari beberapa agama yang melakukannya. Tradisi ataupun budaya menurut penelitian yang dilakukan oleh Vedanti (2020) pada masyarakat adat, memiliki peranan terpenting untuk memutus Pandemi Covid-19 melalui kepercayaan yang dianut dalam lingkup setempat. Dengan demikian tokoh agama juga ikut berpartisipasi dalam penanganan desa dari Pandemi Covid-19. Dalam hal ini setiap tokoh agama memiliki kewajiban untuk turut berpartisipasi dalam penjagaan dan perketatan covid dalam melakukan ibadah di tempat peribadatan (Sarifudin et al., 2020). Setiap tokoh agama melakukan penyampaian informasi kepada masyarakat setempat pada saat melakukan ritual keagamaan, Protokol kesehatan juga tetap diterapkan guna menjaga masyarakat dalam kondisi kondusif dan sehat. Setiap tokoh agama bekerja Sama dengan masyarakat dan juga pemerintah desa setempat untuk menjaga ketertiban serta dalam pengawasan masyarakat melalui satgas Covid dan penerapan protokol kesehatan di Desa Pancasila, Sukoreno.

Kerjasama lintas agama dalam penangan covid menjadi peranan utama untuk menyelaraskan masyarakat di tengah kontestasi ketakutan dan perlawanan terhadap kebijakan yang cenderung menjerumuskan pada bidang sosial ekonomi masyarakat (Mertayasa, 2020). Peranan tokoh agama dapat menjalin kerja sama dengan pemerintah yang berorientasi pada dialog kritis untuk menertibkan masyarakat di tengah Covid-19 (Abdullah, 2020). Di Desa Pancasila Sukoreno yang memiliki keragaman agama dan budaya maka basis utama yang digunakan dalam menghadapi Covid-19 yakni dengan kerja Sama lintas agama dan laku ritual di masyarakat. peranan tokoh agama dan seluruh lapisan masyarakat di suatu desa adat dalam partisipasi aktif yang dilakukan dapat membantu mengamankan daerahnya dengan nilai dan norma yang berlaku di wilayah yang bersangkutan sehingga dapat merentas penyebaran Covid-19 (Rosidin et al., 2020). Generasi muda dan relawan Covid-19 di Desa Sukoreno yang terdiri dari berbagai masyarakat lintas agama juga turut serta dalam mengamankan masyarakat dari penyebaran Covid-19. Penyuluhan dan strategi dilakukan oleh masyarakat dan generasi muda setempat untuk tetap siaga dalam perentasan pandemic Covid19 yang berlangsung. Penyuluhan strategi Covid-19 diharapkan ikut serta membantu mengamankan kesehatan masyarakat dengan dianjurkan mematuhi protokol kesehatan dan kerja sama yang baik antar masyarakat untuk mewujudkan tujuan yang diharapkan bersama 
(Moita et al., 2020). Komunitas yang terbentuk diharapkan dapat bekerja sama dengan baik yang berimplikasi ketertiban dan kesejahteraan sosial di masyarakat dalam memutus rantai Covid-19 di wilayah pedesaan (Dewi et al., 2020).

Menurut hasil penelitian Dewi et al., (2020) masing-masing komunitas harus berada pada fungsi dan tujuan dasar dalam penangan dan pemutusan rantai Covid-19. Kerjasama lintas agama di wilayah Sukoreno berbasis komunitas dapat terlihat dari kegiatan penyemprotan secara berkala di setiap rumah warga, menjaga pos pantau, melakukan pendataan pada masyarakat rentan berdasarkan usia dan daya tahan tubuh dikarenakan penyakit, melakukan bantuan sosial kepada kaum dhuafa terutama masyarakat janda, dan melakukan penertiban apabila memberlangsungkan kegiatan keagamaan. Dalam tugas masing-masing, antara masyarakat satu dengan masyarakat lainnya saling berkontribusi untuk menjaga keamanan desa setempat, sehingga permasalahan mengenai agama dikesampingkan guna mewujudkan kegiatan sosial yang sedang dilaksanakan yang merujuk pada fungsi sosial di masyarakat (Witono, 2020). Kerjasama covid ini juga menimbulkan keakraban yang semakin erat antar masyarakat plural di Desa Pancasila Sukoreno. Masyarakat Desa Pancasila memiliki kemandirian yang cukup tinggi, masyarakat tidak hanya bergantung pada komunitas penangana covid saja untuk menjaga kesehatan dan penertiban, akan tetapi seluruh masyarakat guyub rukun mematuhi protokol kesehatan yang ada di desa sukoreno dan tetap menjalankan sujud.

Bentuk partisipasi masyarakat desa sukoreno terbentuk pada komunitas-komunitas penangan covid 19, seperti relawan covid, karang taruna, dan satgas covid-19. Sedangkan peranan tokoh agama diantaranya menghimbau informasi kepada masyarakat sekitar untuk tetap melaksanakan perintah protokol kesehatan yang diterbitkan oleh pemerintah desa setempat. Partisipasi dalam penanganan Covid ini dilaksanakan oleh sekelompok umat beragama masing-masing dalam lingkup kepercayaan dan tata cara penolakan bala. Tolak Bala merupakan ritual keagamaan dan budaya yang masih dipercaya masyarakat untuk meminta keselamatan dari dampak Pandemi Covid-19 (Hasbullah et al., 2017). Aspek sosial yang mendasar masyarakat lintas agama berperan serta dalam penanganan dan pengawasan covid19. Masyarakat lintas agama tersebut bergabung atas dasar kesadaran pribadi dan jiwa yang sudah tertanam sejak zaman dahulu untuk hidup berdampingan dengan tidak mempermasalahkan terkait agama yang dianut masing-masing masyarakat yang ada (M. Arifin $\&$ Hambali, 2016). Partisipasi merupakan wujud dorongan untuk mengambil posisi dalam suatu keadaan di masyarakat yang tumbuh dan berkembang dari kesadaran pribadi dan juga pengaruh budaya masing-masing wilayah yang masih dipegang erat oleh masyarakat adat (Suaib, 2017b). Budaya menjadikan suatu daya tarik paling kuat untuk mempersatukan masyarakat menghadapi Covid-19. Lain halnya para pemuda desa dan perangkat desa yang sudah mulai terbuka terhadap IPTEK dan pengetahuan lainnya. Namun, berbeda dengan golongan masyarakat tua, mereka masih mempercayai terhadap pagebluk, dan solusi yang ditempuh yakni membuat penangkal terhadap roh-roh jahat pembawa penyakit tersebut. Partisipasi tentunya datang dari pribadi, golongan, dan peranan para elit serta tokoh agama yang ada. Semua bahu membahu bertukar pendapat dalam suat forum untuk menciptakan suasana desa Sukoreno agar tetap kondusif, dan masyarakat tidak panik. Sehinga budaya menjadi pedoman utama dalam menyelesaikan kasus Covid-19 yang meresahkan masyarakat dunia (Amelia \& Zahara, 2020). 
New Normal ini memungkinkan segala kegiatan sudah mulai dilaksanakan, namun hanya dibatasi untuk beberapa orang dan tetap menertibkan kondisi di masyarakat (Taufik \& Warsono, 2020). Kegiatan peribadatan seluruh agama dan aliran kepercayaan yang sempat terhenti untuk melaksanakan ibadah, kini sudah dapat dilaksanakan kembali dengan tetap mematuhi protokol kesehatan. Penganut aliran Sapta Dharma yang relatif lebih sedikit dibandingkan dengan penganut agama yang lainnya ini memudahkan para tokoh agama untuk melakukan agenda yang sudah dipersiapkan sebelumnya. Salah satu tokoh pemuka aliran kepercayaan di Sukoreno yakni Bapak Sunyoto, menggagas adanya kegiatan keagamaan di bawah naungan SILAMAS yang merupakan suatu wadah forum lintas agama yang ada di Kabupaten Jember, SILAMAS merupakan suatu forum yang didalamnya terdapat berbagai aliran agama dan kepercayaan, dimana agama satu dengan lainnya saling berkontribusi untuk menciptakan sikap toleransi yang tinggi di tengah masyarakat Plural yang ada di wilayah Jember, untuk tetap saling menghargai, menghormati, dan membantu antar agama satu dengan lainnya.

Adapun Tujuan dibentuknya SILAMAS diantaranya untuk dapat tersalurkan tujuan kohesi sosial lintas agama di masyarakat, sehingga sikap saling terbuka dan asas gotong royong dalam konteks sosial tetap diutamakan dari kepentingan suatu golongan tertentu. Dalam lembaga SILAMAS sendiri juga terdapat berbagai kegiatan sosial yang dilaksanakan yakni agenda untuk mengadakan bakti sosial yang ditujukan kepada masyarakat. Bakti sosial tersebut ditunjukkan untuk penyaluran bantuan pada warga setempat yang terdampak Covid19 di Desa Sukoreno, Kecamatan Umbulsari. Bakti sosial yang diagendakan oleh Bapak Sunyoto selaku tokoh kepercayaan Sapta Dharma tersebut dilaksanakan pada tanggal 30 Agustus 2020. Sasaran yang paling diutamakan oleh forum SILAMAS yakni khusus bagi masyarakat yang terdampak covid-19. Adapun pemilihan masyarakat yang berhak mendapatkan bantuan sembako tersebut yakni adalah masyarakat kelas ekonomi ke bawah, fakir miskin, anak yatim, dan juga janda ataupun duda yang sudah tua. Pemilihan penerima bantuan sosial ini juga didapatkan dari rekomendasi dari pihak perangkat desa dan juga kader ataupun masyarakat lain yang ikut berpartisipasi, sehingga sasaran utama memberikan bantuan tersebut kepada masyarakat satu desa yang ada di desa Sukoreno, kurang lebih sekitar 300 masyarakat yang berhak mendapatkan bantuan sosial. bakti sosial ini merupakan wujud adanya sinergi dan solidaritas masyarakat lintas agama dalam membantu masyarakat setempat dalam menghadapi pandemic Covid-19 dalam bidang ekonomi, sosial dan budaya yang berkembang di masyarakat.

\section{Simpulan}

Di tengah Pandemi Covid-19 berbagai kebijakan juga diterapkan guna melakukan pendisiplinan dan pencegahan terhadap peneybaran Covid-19 salah staunya di Desa pancasila Sukoreno. Desa sebagai desa berbasis keragaman agama yang berada di Kabupaten Jember. Dalam memutus rantai Covid-19 ini, masyarakat setempat menggunakan basis ritual keagamaan sebagai penghalang dari virus mematikan tersebut. Masyarakat desa Sukoreno cenderung mempercayai bahwa Pandemi Covid merupakan salah satu teguran dari para penguasa ataupun roh jahat untuk menguji iman yang dimiliki oleh manusia. Pandemi Covid19 tidak dijarang juga disebut sebagai Pagebluk oleh masyarakat. Pengetahuan dan pengalaman yang ditinggalkan oleh nenek moyang terdahulu menyebabkan masyarakat desa Pancasila Sukoreno lebih menekankan terhadap kepercayaan agama untuk memutus rantai Covid-19. Masyarakat juga mempercayai bahwa covid-19 merupakan suatu pagebluk yang datang dari kekuatan ghaib untuk memberikan peringatan kepada manusia agar lebih 
mendekatakan dirikepada Tuhan dalam melakukan sujud. Pagebluk menurut perspektif masyarakat Desa Sukoreno yakni merujuk pada hukuman yang diturunkan oleh Tuhan melalui Batara Kala karena kelalalian manusia dan penyimpangan nilai dan norma yang marak di lingkungan masyarakat. sehingga asumsi demikian menegaskan bahwa Covid is pagebluk suatu basis kepercayaan bagi masyarakat yang menyimpan makna kosmis mistis di lingkungan masyarakat Desa Pancasila, Sukoreno.

Ritual keagamaan menjadi basis utama yang dilakukan oleh masyarakat disampng mematuhi protokol kesehatan dalam meretas rantai Covid-19 di Desa Sukoreno. serangkaian laku ritual upacara dan kebudayaan memiliki makna simbolik bagi masyarakat sebagai upaya penyaluran keinginan atau pun doa terhadap kekuatan adikodrati. Adapun ritual yang dilakukan oleh masyarakat Desa pancasila Sukoreno yakni melakukan upacara nunas ica' da melakukan ambengan. Upacara nunas ica' merupakan laku ritual yang dilakukan oleh umat Hindu yang ada di masyarakat Desa Pancasila, sukoreno. sedangkan ambnegan merupakan suatu tradisi kejawen yang diikti oleh seluruh umat beragama untuk memohn perlindungan dan dijauhkan dari covid-19 dan balak lainnya. Selain itu representasi dari tradis dan budaya yang dilakukan ooleh masyarakat lintas agama dengan meletakkan pandan eri di setiap masing-masing rumah. Makna yang terkandung dalam panan eri ini yakni untuk enangkal batara kala yang akan memasuki rumah warga untuk memberikan penyakit kepada pemilik rumah. Sehingga tradis dan budaya lokal menajdi oerientasi uatama dalam mencegah penularan covi dan penaganan Covid pada masyarakat Desa pancasila, Sukoreno, Jember.

Selain itu. Kerjasama lintas agama terlihat dari penangan dan penetapan protokol kesehatan serta kebijakan pemerintah desa setempat yang berelevansi terhadap arahan tokoh agama setempat. Sebagai masyarakat plural yang memegang teguh adat dan tradisi, wilayah Sukoreno menghadapi Pandemi Covid-19 dalam keadaan sujud. Masyarakat tidak terlalu percaya dengan isu yang tengah di bicarakan pada media sosial dan pemberitaan lainnya. Namun, bukan berarti tidak terdapat antisipasi masyarakat untuk dapat melaksanakan aktivitas di tengah pandemic. Kegiatan keagamaan sebagian sempat terhenti karena kebijakan yang sebelumnya telah diberikan pemerintah berdasarkan protokol kesehatan. Akan tetapi solidaritas dan semangat kegotong-royongan terlihat dari masyarakat lintas agama yang mengadakan bakti sosial terhadap masyarakat setempat yang membutuhkan bantuan di tengah dampak sosial, ekonomi pada Pandemi saat ini. Kohesitas sosial keagamaan tidak hanya terlihat pada masyarakat yang memposisikan diri untuk tetap menjaga kesehatan dengan ketetapan yang berlaku dan menggunakan tradisi dalam menangkal bala di masyarakat, namun juga pada kebersamaan dalam tindakan sosial yakni dengan membentuk gabungangabungan Satgas Covid serta relawan untuk membantu masyarakat sekitar. Kerjasama lintas agama ini tidak dapat terbentuk apabila antar masyarakat tidak memiliki sikap untuk saling toleransi antar sesama.

Saran bagi pemerintah sebagai pemegang kebijakan dalam masa Pandemi Covid-19 harus senantiasa melihat kondisi pada masyarakatnya untuk dapat menyesuaikan dengan perumusan protokol kesehatan yang berlaku dengan konteks budaya di wilayah masingmasing.Perumusan kebijakan terkait Covid-19 sebaiknya juga tidak terlalu kaku, mengingat aktivitas sosial, ekonomi dan agama masyarakat di Indonesia saat ini mengalami krisis, sehingga bukan hanya pemerintah saja yang bertindak namun juga perlu sinergi bersama antar masyarakat untuk membangun kesejahteraan di era Pandemi. Kesejehteraan tersebut dapat tercapai dengan memberikan keleluasan bagi pemerintah daerah untuk merumuskan 
kebijakan Covid-19 yang disesuaikan dengan masing-masing wilayah serta berdasarkan kategori zona yang diterbitkan.

Saran bagi masyarakat sebagai basis utama di suatu negara dan hidup di tengah heterogenitas agama maupun budaya sudah seyogannya untuk membangun kerjasama yang baik untuk menghadapi Pandemi Covid-19. Masyarakat harus memiliki sikap toleransi di tengah pluralitas agama baik di lingkup wilayah Desa Pancasila, maupun wilayah lain di Indonesia. Hal ini disebabkan kesatuan masyarakat merupakan aspek terpenting bagi kekuatan negara untuk dapat menghadapi Pandemi Covid-19 seperti sekarang.

\section{Daftar Rujukan}

Abdullah, M. A. (2020). Mendialogkan Nalar Agama dan Sains Modern di Tengah Pandemi Covid-19. MAARIF, 15(1), 11-39. https://doi.org/10.47651/mrf.v15i1.75

Ahwan, Z., \& Marzuki, M. E. (2020). Komunikasi Simbolik dalam Tradisi Bari'an di Jawa Tengah dan Jawa Timur. Al-Ittishol: Jurnal Komunikasi Dan Penyiaran Islam, 1(1), 51-70.

Amelia, K., \& Zahara, C. R. (2020). Minda Mahasiswa Indonesia: Antisipasi Resesi dan Krisis Pangan Akibat Pandemi. Syiah Kuala University Press.

Arifin, M., \& Hambali, K. B. M. K. (2016). Islam dan Akulturasi Budaya Lokal di Aceh (Studi Terhadap Ritual Rah Ulei di Kuburan dalam Masyarakat Pidie Aceh). Jurnal Ilmiah Islam Futura, 15(2), 251-284. https://doi.org/10.22373/jiif.v15i2.545

Arifin, S. (2020). Pagebluk dan Religiusitas Soliter. Arsip Publikasi Ilmiah Biro Administrasi Akademik, o(0), Article 0. http://research-report.umm.ac.id/index.php/API-BAA/article/view/3562

BPS Kab. Jember. (2020, September 28). BPS Kabupaten Jember. Jemberkab.Bps.Gp.Id. https://jemberkab.bps.go.id/publication/2020/09/28/1735a3e864414c78e8180133/kecamatan-umbulsari-dalam-angka2020.html

Buana, R. D. (2017). Analisis Perilaku Masyarakat Indonesia dalam Menghadapi Pandemi Covid-19 dan Kiat Menjaga Kesejahteraan Jiwa. Sosial dan Budaya, Fakultas Syariah dan Hukum Universitas Islam Negeri (UIN) Syarif Hidayatullah Jakarta, 53(9), 1689-1699. https://doi.org/10.1017/CB09781107415324.004

Dewi, C. F., Iwa, K. R., \& Nggarang, B. N. (2020). Asuhan Keperawatan Komunitas Pada Masalah PHBS dan COVID-19 pada Warga Dusun Rejeng Desa Bangka Lelak Kabupaten Manggarai Nusa Tenggara Timur. Randang Tana - Jurnal Pengabdian Masyarakat, 3(3), 148-158. https://doi.org/10.36928/jrt.v3i3.631

Dozan, W., \& Wadi, H. (2021). Agama dan Media Baru (Kesadaran Teologis Manusia di Tengah Pandemi Covid19). Al Iman: Jurnal Keislaman Dan Kemasyarakatan, 5(1), 24-40.

Gani, N. S., Fathiyah, S, N. D., Fitriana, A. D., M.Sila, A., R, F., Yuliarti, A., Thalib, F., Hermansyah, B., Aslam, M., Wandi, Sahid, M., \& Umar, N. J. (2020). Covid 19 dalam Bingkai Komunikasi. IAIN Parepare Nusantara Press.

Hasbullah, H., Toyo, T., \& Pawi, A. A. A. (2017). Ritual Tolak Bala Pada Masyarakat Melayu (Kajian Pada Masyarakat Petalangan Kecamatan Pangkalan Kuras Kabupaten Pelalawan). Jurnal Ushuluddin, 25(1), 83-100. https://doi.org/10.24014/jush.v25i1.2742

Hengki, I. G. B., \& Masmini, N. K. (2020). Melalui Komunitas Desa Adat Dalam Percepatan Penanggulangan Covid-19 dengan Fenomena Sekala-Niskala Masyarakat Bali. Prosiding Webinar Nasional Universitas Mahasaraswati Denpasar 2020, 95-106.

Hindaryatiningsih, N. H. (2016). Model Proses Pewarisan Nilai-Nilai Budaya Lokal dalam Tradisi Masyarakat Buton. Sosiohumaniora, 18(2), 100-107. https://doi.org/10.24198/sosiohumaniora.v18i2.9228

Ilpaj, S. M., \& Nurwati, N. (2020). Pengaruh Tingkat Kematian Akibat Covid-19 Terhadap Kesehatan Mental Masyarakat di Indonesia. Focus: Jurnal Pekerjaan Sosial, 3(1), 16-28. https://doi.org/10.24198/focus.v3i1.28123

Ismail, S. (2018). Kerukunan Hidup Umat Beragama di Desa Pesu Kecamatan Wedi Kabupaten Klaten. AlQalam, 4(1), 30-38. https://doi.org/10.31969/alq.v4i1.653

KBBI Online. (2020). Arti kata pagebluk-Kamus Besar Bahasa Indonesia (KBBI) Online. https://kbbi.web.id/pagebluk. 
Livana, P. H., Suwoso, R. H., Febrianto, T., Kushindarto, D., \& Aziz, F. (2020). Dampak pandemi COVID-19 bagi perekonomian masyarakat desa. Indonesian Journal of Nursing and Health Sciences, 1(1), 37-48.

Maharani, A. (2020, Oktober). Bertambah Kasus Pasien Sembuh, Data Update Terbaru Satgas Kabupaten Jember, Siap Laksanakan Pilkada-Portal Jember. Portaljember. https://portaljember.pikiranrakyat.com/jemberan/pr-16849997/bertambah-kasus-pasien-sembuh-data-update-terbaru-satgaskabupaten-jember-siap-laksanakan-pilkada.

Mertayasa, I. K. (2020). Penggunaan Sawen pada Masa Pandemi Covid-19 di Desa Meko. Dharma Duta, 18(1), 58-71. https://doi.org/10.33363/dd.v18i1.483

Moita, S., Sarmadan, S., Kasim, S. S., \& Bahtiar, B. (2020). Penyuluhan Strategi Penguatan Partisipasi Masyarakat dalam Menghadapi Pandemi COVID-19. Jurnal Abdidas, 1(6), 518-526. https://doi.org/10.31004/abdidas.v1i6.109

N. Funay, Y. E. (2020). Indonesia dalam Pusaran Masa Pandemi: Strategi Solidaritas Sosial berbasis Nilai Budaya Lokal. Jurnal Sosiologi Agama Indonesia (JSAI), 1(2), 107-120. https://doi.org/10.22373/jsai.v1i2.509

Nasrulloh, L. (2020). Nilai Edukasi Ritual Bereqe Lombok pada Masa Pandemi Covid-19: Sebuah Kajian Etnografi. In Kesiapan Dunia Pendidikan Menghadapi Era New Normal (Ragam Perspektif Praktisi Pendidikan) (pp. 33-46). IAINPAREPARE Nusantara Press. http://repository.iainpare.ac.id/1689/

Ningrum, A. P. (2021). Eksistensi Pecalang dan Banjar Adat dalam Pencegahan Covid-19 di Tanggahan Tengah. Pariksa, 4(2), 62-72.

Rosidin, U., Rahayuwati, L., \& Herawati, E. (2020). Perilaku dan Peran Tokoh Masyarakat dalam Pencegahan dan Penanggulangan Pandemi Covid-19 di Desa Jayaraga, Kabupaten Garut. Umbara, 5(1), 42-50. https://doi.org/10.24198/umbara.v5i1.28187

Rumilah, S., Nafisah, K. S., Arizamroni, M., Hikam, S. A., \& Damayanti, S. A. (2020). Kearifan Lokal Masyarakat Jawa dalam Menghadapi Pandemi. SULUK: Jurnal Bahasa, Sastra, Dan Budaya, 2(2), 119-129. https://doi.org/10.15642/suluk.2020.2.2.119-129

Sarifudin, S., Maya, R., Maulidina, Y., Rahayu, S., \& Anggraini, R. P. (2020). Pemberdayaan Masyarakat Perkotaan di Masa Pandemi Covid 19 dalam Meningkatkan Kesejahteraan, Kesehatan dan Pendidikan Melalui Program Ecomasjid di Kelurahan Margajaya Kecamatan Bogor Barat Kota Bogor. Khidmatul Ummah: Jurnal Pengabdian Kepada Masyarakat, 1(01), 39-53.

Setiawan, H., \& Kurniawan, F. (2017). Pengobatan Tradisional Sebuah Kajian Interaksionisme Simbolik. Paradigma: Jurnal Filsafat, Sains, Teknologi, Dan Sosial Budaya, 23(2), 57-66. https://doi.org/10.33503/paradigma.v23i2.348

Setio, R. (2020). Poshumanisme dalam Alkitab: Sebuah Renungan Biblis di Masa Covid-19. KENOSIS: Jurnal Kajian Teologi, 6(2), 122-145. https://doi.org/10.37196/kenosis.v6i2.186

Somawati, A. V., Adnyana, K. S., Darmawan, I. P. A., Dewi, N. P. D. U., Untara, I. M. G. S., Suadnyana, I. B. P. E., Paramita, I. B. G., Wibawa, G. Y. S., Gunawijaya, I. W. T., Srilaksmi, N. K. T., \& Indrayasa, K. B. (2020). Bali vs COVID-19. Nilacakra.

Suaib, H. (2017a). Nilai-Nilai Kearifan Lokal dan Modal Sosial Dala Pemberdayaan Masyarakat Suku Moi. An1mage. https://books.google.com/books/about/Suku_Moi.html?hl=id\&id=c8Y0DwAAQBAJ

Suaib, H. (2017b). Suku Moi: Nilai-Nilai Kearifan Lokal dan Modal Sosial dalam Pemberdayaan Masyarakat. An1mage.

Sunuantari, M., \& Zarkasi, I. R. (2020). Tata kelola black zone covid-19 berbasis komunitas. In Komunikasi dan Community Empowerment (1st ed.). MBridge Press. https://eprints.uai.ac.id/1440/

Susanto, D., Rosidah, A., Setyowati, D. N., \& Wijaya, G. S. (2020). Tradisi Keagamaan Sebagai Bentuk Pelestarian Budaya Masyarakat Jawa Pada Masa Pandemi. SULUK: Jurnal Bahasa, Sastra, Dan Budaya, 2(2), 107118. https://doi.org/10.15642/suluk.2020.2.2.107-118

Taufik, T., \& Warsono, H. (2020). Birokrasi Baru untuk New Normal: Tinjauan Model Perubahan Birokrasi dalam Pelayanan Publik di Era Covid-19. Dialogue: Jurnal Ilmu Administrasi Publik, 2(1), 1-18. https://doi.org/10.14710/dialogue.v2i1.8182

Ulya, H. N. (2020). Alternatif Strategi Penanganan Dampak Ekonomi Covid-19 Pemerintah Daerah Jawa Timur pada Kawasan Agropolitan. El-Barka: Journal of Islamic Economics and Business, 3(1), 80-109. https://doi.org/10.21154/elbarka.v3i1.2018 
Jurnal Integrasi dan Harmoni Inovatif Ilmu-Ilmu Sosial, 1(5), 2021, 666-680

Vedanti, K. V. (2020). Relevansi Nilai Ritual Tolak Bala Lanting Bamban pada Pencegahan Dampak Pandemi COVID-19. Satya Widya: Jurnal Studi Agama, 3(1), 86-97. https://doi.org/10.33363/swjsa.v3i1.463

WHO Indonesia | World Health Organization. (2020). https://www.who.int/indonesia

Witono, W. (2020). Partisipasi Masyarakat dalam Ketahanan Keluarga pada Masa Pandemi Covid-19. JMM (Jurnal Masyarakat Mandiri), 4(3), 396-406. https://doi.org/10.31764/jmm.v4i3.2525

Yasa, I. W. P. (2020). Tri Hita Karana untuk Pencegahan COVID-19 di Bali. Jurnal Socius: Journal of Sociology Research and Education, 7(1), 54-66. https://doi.org/10.24036/scs.v7i1.176

Yusuf, M., \& Basyid, A. (2020). Tradisi “Mbeleh Wedhus Kendhit” Sebagai Sarana Tolak Balak di Masa Pandemi Covid-19. Sosial Budaya, 17(2), 149-159. https://doi.org/10.24014/sb.v17i2.11272 